\title{
LAW, DEMOCRACY, AND CONSTITUTIONALISM: REFLECTIONS ON EVANS v ATTORNEY GENERAL
}

\author{
T. R. S. ALLAN*
}

ABSTRACT. The difference of judicial opinion in the Supreme Court in Evans provokes reflection on fundamental constitutional principles, such as parliamentary sovereignty and the rule of law. A statute that on its face seems to permit a government minister to override a judicial decision of which he disapproves inevitably raises acute concern; the correct reading of the statute depends on the most persuasive integration of basic principles, placing the text within its wider constitutional context. The Justices deployed distinctions between law, fact, and public interest in rather different ways, reflecting their divergent interpretative approaches. The role of constitutional convention is also of particular interest-central to the legal issues arising, on one view, but largely irrelevant on another. At the root of these disagreements lie contrasting conceptions of law and adjudication.

KEYWORDS: Parliamentary sovereignty, rule of law, constitutional convention, statutory interpretation, law and fact, public interest, ministerial override

\section{INTRODUCTION}

We can sometimes learn a good deal about public law and legal interpretation by reflecting in some detail on a particular case, especially when the case is widely agreed to be one of constitutional importance. Evans v Attorney General presents us with a division of opinion in the Supreme Court that reflects, at root, divergent attitudes to fundamental constitutional doctrine and — even further down-different understandings of the concept of law itself. ${ }^{1}$ Confronted by a statute that appeared to allow a government minister to

\footnotetext{
* Address for correspondence: Professor T. R. S. Allan, Pembroke College, Cambridge CB2 1RF. Email: trsa2@cam.ac.uk.

1 Evans v Attorney General [2015] UKSC 21, [2015] 2 W.L.R. 813.
} 
veto a judicial decision of which he disapproved, the Justices were forced to consider the relationship between parliamentary sovereignty and the rule of law. Could the Freedom of Information Act 2000 properly be construed as having such a surprising result, so antithetical to our usual assumptions about the proper relationship between the executive and the courts? How should the tension between respect for the apparent will of Parliament, on the one hand, and adherence to the rule of law, on the other, be resolved? Any coherent reconciliation of these basic doctrines, however, must itself draw on an underlying conception of law, repudiating rival approaches or assumptions. From a perspective that emphasizes authoritative sources, distinguishing the content of law from moral or political principle, the doctrine of parliamentary sovereignty provides useful finality and certainty. Constitutional principle or common law presumption quickly gives way to plain statutory instructions to a contrary effect; the legislative will is paramount even if it appears to do injustice in particular cases. By contrast, those who put their faith chiefly in the rule of law, as a substantive constitutional doctrine, invoke a different account of the concept of law. Authoritative sources are identified, interpreted and (when necessary) moderated on the basis of reasoned argument. Moral deliberation comes to the fore as the defining characteristic of a system of law grounded on defensible principles of justice or fairness-principles that judges have a duty to develop and articulate in the course of adjudication. $^{2}$

Evans illustrates these points to perfection. Those Justices willing to take the statutory instructions at face value, swallowing their discomfort over such a dubious interference with the normal separation of powers, were also keen to insist on clear distinctions between law-and hence the judicial role-and moral or political judgment acceptably reserved for politicians. A marked deference to statute, literally construed, was

\footnotetext{
2 See further T.R.S. Allan, The Sovereignty of Law: Freedom, Constitution, and Common Law (Oxford 2013), ch. 1. Compare with Stephen R. Perry, "Judicial Obligation, Precedent and the Common Law" (1987) 7 O.J.L.S. 215, at 215-18.
} 
accompanied by a parallel deference to ministerial discretion, which Parliament was free to bestow as it chose. In contrast, those Justices unwilling to countenance a threat to principles of the rule of law-to the vision of law they sought to defend-were not only resistant to the claims of literal meaning. They also looked askance at rigid doctrinal boundaries, supposedly marking out public law from moral or political principle, insisting that executive discretion be subjected to the discipline of reasoned argument and deliberation.

One prominent feature of the controversy concerned the relationship between law and convention. The requirements of constitutional convention, as regards the relationship between ministers and the heir to the throne, were a significant thread in the arguments over the balance of public interests for and against disclosure of documents. While the judgments display some uncertainty about how the pertinent conventions should be classified-whether law, fact, or aspects of the public interest-the division of opinion over their role in the correct disposal of the case is very revealing. The close interaction between law, convention, and public interest, implicit in the opinions of the majority of Justices, was denied by the dissentients, keen to stress the differences between these separate sources of legal and political authority. Evans, accordingly, illustrates the deficiencies of any neat conceptual distinction between law and convention in the context of adjudication. To presuppose that distinction is to beg important questions at issue. Dicey's admonition that the "customs, practices, maxims, or precepts" that make up convention must not be considered law-they were neither enforced nor recognized by courts—cuts little ice in interpretative legal reasoning as distinct from descriptive political science. $^{3}$

\footnotetext{
3 A. V. Dicey, Lectures Introductory to the Study of the Law of the Constitution in J. W. F. Allison (ed.), Oxford Edition of Dicey (Oxford 2013), vol. I, 185. If Dicey meant only that conventions were not recognized as legal rules (see Colin Munro, "Laws and Conventions Distinguished" (1975) 91 LQR 218, at 229 - 31) his descriptive categorization is largely irrelevant to adjudication, which may sometimes require moral or political judgment about the correct content and scope of such rules.
} 
From an internal, interpretative perspective-the viewpoint of the judge or lawyer deliberating about the content of the law-the requirements of constitutional convention may occupy a significant role. Admittedly, a lawyer's approach will always reflect his underlying jurisprudential commitments, whether explicit or merely implicit in his style of reasoning. Adherence to a positivist conception of law may encourage the marginalization of convention, law being treated as the product of certain authoritative official sources that exclude the settled practices of politicians. ${ }^{4}$ From a more thoroughgoing interpretative viewpoint, by contrast-an interpretative stance that resists the exclusive authority of a narrow range of official sources of law-political practice, exemplifying commitment to general principles of constitutional propriety, may provide a compelling guide to the requirements of constitutional law. ${ }^{5}$ Reliance on convention as a crucial determinant of a specific question of law, linked to assessments of the public interest, suggests a non-positivist, more open-ended conception of law: law is ultimately a reflection of political morality, the product of continuing, contextual deliberation about the requirements of justice and the public good. ${ }^{6}$

Evans, a Guardian journalist, sought disclosure of correspondence between the Prince of Wales, heir to the British throne, and various government ministers-the so-

\footnotetext{
${ }_{4}$ A positivist conception of law treats law as fundamentally the product of authoritative sources, any overlap with moral or political principle being dependent on the law's contingent content: official practice is determinative, rather than an interpreter's appraisal of the moral implications of practice. See generally H.L.A. Hart, The Concept of Law, 2nd ed. (Oxford 1994). Dicey treats conventions as a code of "constitutional or political ethics" as opposed to (positive) law: Lectures Introductory, previous note, 185.

${ }^{5}$ I have made this argument at length in Allan, Sovereignty of Law, ch. 2.

6 Compare Ronald Dworkin, Law's Empire (London 1986); but see also Allan, 'Interpretation, Injustice, and Integrity' (2015) O.J.L.S. 1, doi: 10. 1093/ ojls/gqv014.
} 
called "black-spider memos"—under the Freedom of Information Act 2000. In this correspondence Prince Charles had pressed his views about various matters of public policy; there was arguably a strong public interest in disclosure of the nature and extent of his influence on government decision-making. The Information Commissioner upheld the Government's refusal to disclose the documents on the ground that they were exempt from disclosure under provisions of the Act applicable to communications with the Royal Family and information held in confidence. ${ }^{8}$ Being qualified rather than absolute exemptions, the test was whether "in all the circumstances of the case, the public interest in maintaining the exemption outweighs the public interest in disclosing the information" (section 2). The Upper Tribunal, on appeal, conducted a full hearing, which included receipt of expert evidence on the constitutional conventions applicable to the status and responsibilities of the Prince of Wales. The Tribunal ruled in favour of disclosure. However, the Attorney General invoked section 53 of the Act, allowing an "accountable person" (for present purposes, the Attorney) to give a certificate stating that he has "on reasonable grounds" formed the opinion that the statute permits non-disclosure. The Divisional Court, on judicial review, upheld the certificate, but on appeal the Court of Appeal held it to be an unlawful exercise of the ministerial veto. On further appeal the Supreme Court was divided, a majority upholding the Court of Appeal's decision but Lord Hughes and Lord Wilson dissenting.

\footnotetext{
7 The correspondence in issue took place between September 2004 and March 2005. A further application for environmental information under the Environmental Information Regulations 2004, passed to give effect to Council Directive 2003/4 / E.C., can for present purposes be ignored.

8 Freedom of Information Act 2000, ss 37, 40 and 41.
} 


\section{STATUTORY INTERPRETATION AND CONSTITUTIONAL PRINCIPLE}

In the leading opinion, with which Lord Kerr and Lord Reed agreed, Lord Neuberger objected to the Attorney General's exercise of his ministerial veto on fundamental constitutional grounds. It was a basic principle of the rule of law that a judicial decision is binding on the parties and cannot be set aside by anyone, least of all by the executive. ${ }^{9}$ It was also fundamental to the rule of law that decisions and actions of the executive are normally reviewable by the court at the suit of an interested citizen. Section 53 , as interpreted by the Attorney General, flouted both principles: “It involves saying that a final decision of a court can be set aside by a member of the executive (normally the minister in charge of the very department against whom the decision has been given) because he does not agree with it." ${ }^{10}$ Lord Neuberger noted that the Upper Tribunal is an independent court—both an expert tribunal and a superior court of record, "effectively with the same status as the High Court of Justice". ${ }^{11}$ Invoking the "principle of legality" affirmed in previous cases, he applied the strong presumption that Parliament does not intend to legislate contrary to the rule of law. ${ }^{12}$ In providing, in subsection (4)(b), that the time for issuing a certificate (twenty days) was effectively to be extended where an appeal was brought against the Commissioner's decision, the Act apparently extended the power

\footnotetext{
9 Compare with Lord Judge C.J. in the Divisional Court [2013] EWHC 1960 (Admin), [2014] Q.B. 855, at [12]: "It is fundamental to the constitutional separation of powers, the independence of the judiciary, and the rule of law itself that, although judicial decisions may be reversed by legislation (but very rarely with retrospective effect) ministers are bound by and cannot override judicial decisions: in our constitution that power is vested in Parliament."

10 Evans [2015] UKSC 21, at [52].

11 Ibid., at [16].

12 See e.g. R. $v$ Secretary of State for the Home Dept, ex p. Pierson [1998] A.C. 539, 575 (Lord Browne-Wilkinson), 591 (Lord Steyn).
} 
to issue a certificate to a decision confirmed by a tribunal or an appellate court. But that was "a very long way away indeed from making it 'crystal clear' that that power can be implemented so as to enable a member of the executive effectively to reverse, or overrule, a decision of a court or a judicial tribunal simply because he does not agree with it" ${ }^{13}$

Lord Neuberger agreed that the correct interpretation of section 53 was that adopted by the Court of Appeal. According to Lord Dyson M.R., a certificate could be lawfully issued only in the event of a "material change of circumstances" since the Tribunal's decision or where that decision was "demonstrably flawed in fact or in law". ${ }^{14}$ While it would often, in practice, be open to the parties (as in this case) to rely on evidence or even exemptions that were not considered by the original decision-maker, when invoking the jurisdiction of the Commissioner or the First-tier Tribunal, it would be more difficult to do so on appeal to the Upper Tribunal or the Court of Appeal, which must be an appeal on a point of law. There was also a real possibility, at least, that there could be matters arising that indicated serious flaws in a Tribunal determination but where no appeal lay —if it were a second appeal—because no important point of law or practice was raised. Section 53 therefore retained a "potential function", where a court or tribunal had held in favour of disclosure, even if it would be likely to arise "on few occasions and on limited grounds". ${ }^{15}$

${ }^{13}$ Evans [2015] UKSC 21, at [58]. Compare Jackson v Attorney-General [2005] UKHL 56, at [159]: 'The courts will ... decline to hold that Parliament has interfered with fundamental rights unless it has made its intentions crystal clear' (Lady Hale).

14 Evans [2014] EWCA Civ. 254, [2014] Q.B. 855, at [38] (cited by Lord Neuberger at [71]). This followed Simon Brown L.J.'s approach in R. $v$ Secretary of State for the Home Dept, ex p. Danaei [1998] I.N.L.R. 124 in relation to a ministerial decision that contradicted an earlier decision of the special adjudicator on the facts relevant to an asylum claim.

15 Evans [2015] UKSC 21, at [78]. It was not impossible to envisage circumstances, accordingly, in which new grounds or evidence, relevant to issue of a certificate, might come to the attention of the accountable person, enabling him to act within the very limited twenty day period allowed (see [75]). 
In their dissenting opinions, Lord Hughes and Lord Wilson rejected this reading of the Act. Lord Hughes objected that, while the statute could have stated the conditions for issue of a certificate identified by the Court of Appeal, it did not actually do so. Although he agreed, in principle, that "Parliament will not be taken to have empowered a member of the executive to override a decision of a court unless it has made such an intention explicit", he considered that Parliament had "plainly shown such an intention in the present instance". ${ }^{16}$ Lord Wilson's dissent was even more forthright. In his view the Court of Appeal did not interpret section 53 at all: "It re-wrote it." Their decision invoked "precious constitutional principles" but "among the most precious is that of parliamentary sovereignty, emblematic of our democracy" ${ }^{17}$ The result of the interpretation favoured by counsel for Evans was that it would "almost never" be reasonable for an accountable person to disagree with a court's decision in favour of disclosure; and the trouble was that "Parliament made clear, by subsection (4)(b), that such a certificate could be given in such circumstances". ${ }^{18}$ While Lord Wilson accepted that the possibility of challenge by way of appeal would affect the legality of any certificate, in the present case no such consideration arose. Disagreement with the evaluation of public interests by the Upper Tribunal (under section $2(2)(b))$ could not have amounted to a point of law on which the Government might have appealed to the Court of Appeal: “There was only one course open to it and then only if it had reasonable grounds for disagreement: it was to give a certificate under section 53."19 Accordingly, the present circumstances "constituted a paradigm example of the area of the section's lawful use".

\footnotetext{
16 Ibid., at [154].

17 Ibid., at [168].

18 Ibid., at [177]. Section 53(4) defines the "effective date", for purposes of s 53(2), as the day on which (a) the decision notice is given to a public authority or (b) "an appeal under section $57 \ldots$ is determined or withdrawn".

19 Evans [2015] UKSC 21, at [178].
} 
Lord Mance, with whom Lady Hale agreed, adopted a position somewhere between the other majority judges and the dissentients. On the one hand, he demurred at Lord Neuberger's very narrow interpretation of section 53, granting the possibility that a certificate might lawfully express a minister's disagreement with the balance of public interests as determined by a court or tribunal. On the other hand, he denied that in the present case the Attorney General had given cogent reasons for such disagreement. Accordingly, Mance and Hale preserved the Upper Tribunal's findings from governmental attack by sharply narrowing, in practice, the circumstances in which the minister could intervene. While it would require "the clearest possible justification" before a certificate might validly override either judicial findings about the relevant background circumstances or rulings of law, disagreement about the relative weight to be attributed to competing public interests was permissible. The evaluation of the respective public interests was a matter that a certificate could address "by properly explained and solid reasons". ${ }^{20}$ In the present case, however, the Attorney General had not undertaken an appropriate weighing of interests: he had, on the contrary, undertaken "his own redetermination of the relevant background circumstances" ${ }^{21}$ He had impermissibly challenged the constitutional position, encapsulated in constitutional convention, as explored and clarified by the Upper Tribunal.

Part of the court's interpretative task lay in ascribing appropriate meaning to the ministerial power to issue a certificate on "reasonable grounds". Lord Hughes treated this requirement as one of simple rationality, apparently satisfied merely by observing that the Attorney's view was shared by the Commissioner. Lord Wilson conceded that the Attorney's opinion would be reasonable only if, in his statement of reasons, he demonstrated engagement with the Tribunal's determination; but he had done so (in Wilson's view) by stating his disagreement with its approach to the evaluation of the rival

\footnotetext{
20 Ibid., at [130].

21 Ibid., at [131].
} 
public interests. Lord Neuberger, in contrast, insisted that the meaning of "reasonable grounds" was highly dependent on context, and it was not reasonable for an accountable person to issue a certificate simply because he took a different view from that "adopted by a court of record after a full public oral hearing" ${ }^{22}$ Lord Mance thought that the Attorney General faced a "higher hurdle" than mere rationality, being required to give reasons that would withstand judicial scrutiny. The requirement of reasonable grounds fell to be understood, therefore, in the light of each judge's wider analysis of the nature and scope of the ministerial veto.

There are undeniable problems or disadvantages with each of the various interpretations defended. Lord Neuberger's interpretation might surprise a parliamentarian who had not reflected on the constitutional implications of a more literal reading. Lord Mance shared Lord Wilson's reluctance to ascribe a meaning to section 53 that made it all but inapplicable in practice to decisions of the Upper Tribunal, noting the further complexities or incongruities that arose if the certificate could be more readily issued in the case of a decision by the Information Commissioner (from whom there would in any event be a right of appeal on both fact and law). But Mance's via media was itself precarious. Neuberger observed that it was unrealistic to expect a minister to produce in twenty days an analysis capable of satisfying Mance's high standards of justification, if indeed (he suggests) it were possible in practice to meet such standards at all. And why, if the minister were entitled to overturn the Tribunal's view about the public interests, should he not be able to disagree about the relevant facts?

The dissenting opinions avoid these problems; but they have to confront the objection that they sanction the unconstitutional overriding of a judicial decision by a member of the executive. And it is no answer to say that the dissentients deferred to the will of Parliament unless we are confident that on the best construction-all things considered-their interpretation of the statute was correct. Insofar, for example, as Lord

22 Ibid., at [88]. 
Hughes and Lord Wilson appeared to claim intrinsic superiority for an interpretation that invokes a standard, non-contextual sense of "reasonable grounds", it was a spurious claim: a literal reading needs as much justification as a non-literal one. If the dissentients were correct, it would only be because their reading made better sense of the Act overall, having regard to its general purposes and the wider constitutional context. ${ }^{23}$

If the Act is treated as a self-contained code, impervious to broader considerations of constitutional propriety, the dissenting opinions are perhaps the most persuasive. But few common lawyers would contend that parliamentary sovereignty necessarily imposed such an approach. The doctrine is widely and reasonably considered tolerable only because judges are expected to strive for harmony as far as possible between legislative instructions, as regards the immediate context, and constitutional principle, reflecting the background moral and political milieu usually taken for granted. Everything depends, therefore, on the general theory of legal interpretation we favour: what is legally permitted or required reflects, at some level, what in our considered opinion it would be morally defensible to permit or require.

We should, then, be wary of Lord Hughes's reliance on "the plain words of the statute" ${ }^{24}$ It is true, as he observed, that section 53(2) could have expressly provided for the limitations on ministerial discretion stated by Lord Neuberger, but did not. The issue is not, however, whether the bill's promoters-Lord Hughes spoke simply of "Parliament" — would have been likely to include these limitations if they had been intended. The legal issue is, instead, whether a court should read in such limitations on

\footnotetext{
23 Lord Wilson was clearly entitled to emphasize the "unique array of safeguards" that operated to circumscribe a "unique" executive power. In particular, the power applied only to a decision notice served on a government department and the accountable person had in England to be a Cabinet minister or the Attorney General, who by convention should consult the Cabinet collectively. Moreover, a copy of the certificate was required to be laid before each House of Parliament, providing "the facility for almost immediate democratic scrutiny of the use of the override". See ibid. at $\{172\}$.

24 Ibid., at [155].
} 
constitutional grounds. If any suggestion of such limits made during parliamentary proceedings would have provoked "a decisive and negative response", as Lord Hughes speculated, it might still be the case that those responding would have failed to appreciate the constitutional implications of their preferred construction.

In short, the truth of Lord Hughes's assertion that "it is an integral part of the rule of law that courts should give effect to Parliamentary intention" hinges on the meaning we attribute to "Parliamentary intention". If it means the intention of the bill's sponsors, or the draftsman, or even the hypothetical expectations of the typical member of Parliament voting in favour, then the assertion is very doubtful. Since the "intention" of a collective body can only be constructed by reference to the language used, on one hand, and the apparent objectives of the statute, on the other, there is no escape from an interpretative engagement with constitutional principle. We cannot ask for directives about how much weight to give to principle in making sense of the language employed; such directives would, in any event, present similar problems of construction. We can sustain the rule of law only by reflecting for ourselves on what, in all the circumstances, is the most defensible interpretative conclusion. ${ }^{25}$

Whether Lord Wilson's forthright criticism of the Court of Appeal is justified, then, depends on how the line between interpretation and "rewriting" should be drawn: the latter is only a pejorative label for an interpretation regarded as incorrect. While a presumption in favour of ordinary meaning may produce a better match with the expectations of certain members of Parliament, or with those of other persons or officials, its force will depend on the context. ${ }^{26}$ The greater the threat to legal or constitutional principle, the more firmly should the courts insist on explicit statutory language-

\footnotetext{
${ }^{25}$ See further Allan, Sovereignty of Law, ch 5. Compare with Dworkin, Law's Empire, 313 - 37.

26 "Ordinary meaning" is intended to capture the idea of the "plain words" of the statute-literal meaning adapted as necessary to make sense of the immediate legislative instructions, disregarding broader matters of constitutional principle.
} 
language which, by anticipating judicial construction, sensitive to principle, limits or excludes the preferred judicial response. The court must be confident that the pertinent issues of principle have been addressed in a manner that any conscientious member of Parliament, attentive to the bill's likely consequences, could reasonably have grasped. ${ }^{27}$ And a grave enough threat will support a decisive rejection of ordinary meaning: no such conscientious parliamentarian can be supposed to have sanctioned radical breaches of the rule of law—violations of the kind that undermine legitimate governance.

If, moreover, parliamentary sovereignty is "emblematic of our democracy", it is reasonable to suppose that its nature and scope, properly considered, express a defensible conception of democracy. A defensible conception of democracy is arguably one that confers great power on a majority of elected representatives on the understandingreflected in suitable modes of judicial interpretation-that they should not interfere too greatly with basic features of the rule of law and separation of powers. The conferral of powers on the executive to override an unfavourable judicial decision must be expected to attract suspicion. The strong temptation to "maintain the supremacy of the astonishingly detailed" decision of the Upper Tribunal, to which the Court of Appeal in Lord Wilson's view wrongly succumbed, was provoked by an appropriately strong desire to preserve the integrity of the rule of law. ${ }^{28}$ It does not follow, of course, that the narrow interpretation of section 53 preferred by the two highest courts was necessarily correct; but any presumption in favour of ordinary meaning was far too weak in these circumstances to do any interpretative work on its own.

Once it is conceded, moreover, that the existence of reasonable grounds must be determined in the context of the Tribunal's decision, having regard to the Tribunal's reasoned judgment, it is hard to make sense of that requirement in the absence of argument pointing to manifest error or change of circumstances. A mere rejection of the

27 Compare R. $v$ Secretary of State for the Home Dept, ex p. Simms [2000] 2 A.C. 115, 131 (Lord Hoffmann), cited by Lord Neuberger in Evans [2015] UKSC 21, at [56].

28 Evans [2015] UKSC 21, at [168]. 
Tribunal's conclusions, even if explicit, hardly amounts to more than the assertion of a contrary opinion, unaffected by those conclusions. Lord Judge, in the Administrative Court, held that "the principle of constitutionality requires the minister to address the decision of the Upper Tribunal ... head on, and explain in clear and unequivocal terms the reasons why, notwithstanding the decision of the court, the executive override has been exercised on public interest grounds". ${ }^{29}$ If, however, the minister is empowered merely to state his disagreement with the basis of the Tribunal's conclusion, asserting a contrary view, it is hard to see how "close judicial scrutiny" can provide what Lord Judge considered was a "necessary safeguard for the constitutionality of the process". ${ }^{30}$ Davis L.J., who thought that the situation called for "appropriately close scrutiny by the courts on a judicial review challenge", agreed that the reasons given in a certificate must be "cogent". ${ }^{31}$ But a cogent rejection of the Tribunal's judgment would surely have to identify its faults and failings. In the present case, as Lord Mance observed, the Attorney rode roughshod over the Tribunal's detailed refutation of the principal elements of his position. The illusory nature of the supposed judicial scrutiny is exposed by Davis L.J.'s robust dismissal of the claimant's "underlying submission" that "the accountable person is not entitled simply to prefer his own view to that of the tribunal" ${ }^{32}$ It was enough, in Davis's view, that the Attorney's reasons made "sense", echoing those previously given by the Commissioner. ${ }^{33}$

Mark Elliott's analysis of these issues is rather different. ${ }^{34}$ He considers that Lord Neuberger performed "radical interpretive surgery" on the statute: "Lord Neuberger's

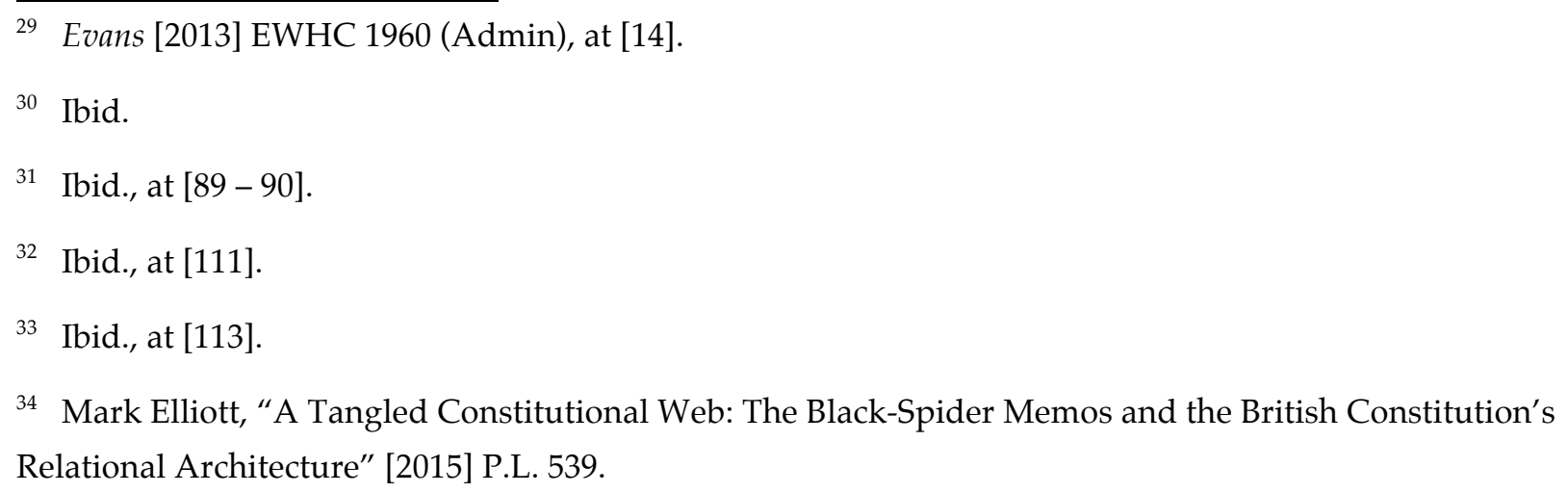


construction is undeniably strangulated, the interpretations of the other Justices being obviously far less strained." ${ }^{\prime 35}$ Elliott acknowledges that parliamentary sovereignty does not demand adherence to "the literal meaning of the words used by Parliament"; there is scope for judicial interpretation, applying "relevant constitutional principles". But parliamentary sovereignty is not, he contends, "infinitely elastic", permitting any amount of "judicial violence to statutory provisions". ${ }^{36}$ Elliott is worried that Neuberger's treatment of section 53 may have crossed "the fine line that distinguishes bold statutory construction from judicial intransigence in the face of a constitutionally offensive statutory provision". ${ }^{37}$ These concerns, however, imply that a literal reading enjoys an automatic priority, questions of legitimacy arising only when a more nuanced, non-literal reading is substituted. But that view is open to challenge. If we think that statutory interpretation should respect constitutional principle-reflecting the weight or importance of rule-of-law considerations-the outcome is neither strangulated nor strained: it is what the Act, correctly interpreted, means or requires.

Even if parliamentary sovereignty does not permit the courts to treat the statutory text as what Elliott calls "a blank canvas on which to project constitutional values", it does not follow that an interpretation that departs significantly from literal meaning does "violence" to the text. The "fine line" that Elliott fears Neuberger may have crossed can be located only from within an interpretation that gives due weight to all relevant principles: it is the product of competent legal interpretation, not an external constraint on interpretation, confining its scope from the outset. The strength of Neuberger's objections to a literal reading - if we accept their cogency-is all the justification needed. There is no artificial stopping point before an interpretation is reached that does, in our considered opinion, satisfy all the pertinent dimensions of political morality. The balance of general principles is key to the true meaning of the text. Parliamentary sovereignty is arguably as

\footnotetext{
35 Ibid., 548.

36 Ibid.

37 Ibid., 549.
} 
elastic as is necessary to ensure that obedience to the legislative will is morally defensible, having regard to the consequences of alternative constructions. ${ }^{38}$

\section{CONSTITUTIONAL CONVENTION AND CONSTITUTIONAL LAW}

It is hard to exaggerate the importance of an analysis of constitutional convention to a correct determination of the legal issues arising. Even if on its face the Freedom of Information Act required only a balancing of interests for and against disclosure, making no mention of convention, the outcome necessarily reflected an understanding of the general constitutional context. And established conventions concerning the relations between ministers and the monarch, on the one hand, and between ministers and the heir to the throne, on the other, formed a critical part of that context. The relevant conventions must bear much of the weight of arrangements that seek to safeguard the position of the monarchy, insulating the Sovereign from the danger of entanglement in political controversy while permitting the freedom of speech necessary for the health of democracy. The Upper Tribunal observed that "debate about the extent and nature of interaction between government and the royal family, and how the monarchy fits in to our constitution, goes to the heart of understanding the constitutional underpinning of our current system of government" ${ }^{39}$ These were "important and weighty considerations in favour of disclosure". Respect for settled convention was an integral part of any serious appraisal of the case presented for non-disclosure; and, accordingly, adherence to the proper boundaries of convention was critical to the justification of an exemption from the ordinary demands of openness and freedom of speech.

\footnotetext{
38 See further Allan, Sovereignty of Law, chs. 4, 5.

39 Evans [2012] UKUT 313 (AAC), at [142].
} 
A number of key conventions were identified and distinguished. The "cardinal convention" requires the monarch to act on ministerial advice, usually given by the Prime Minister on behalf of the Government. ${ }^{40}$ The "tripartite convention" refers to Walter Bagehot's familiar account of the monarch's "right to be consulted", her "right to encourage", and her "right to warn". ${ }^{41}$ Exchanges between monarch and Prime Minister or between monarch and other ministers under the aegis of this convention remain confidential, the Sovereign being required to observe a strict political neutrality in public. The Upper Tribunal found "ample reason to justify the principle that the internal operation of these two conventions is not revealed, at least until after a long time has passed". ${ }^{42}$ The "education convention" provided for the confidentiality of communications between ministers and the heir to the throne intended to instruct him in the business of government. The Tribunal resisted as tendentious Professor Brazier's labelling of it as the "apprenticeship convention". ${ }^{43}$ The public nature of Prince Charles's support for various policies and causes was inconsistent with the idea that similar advocacy, when pursued by private correspondence, was conducted as a form of rehearsal for his future role as Sovereign. ${ }^{44}$

In the familiar manner, faithful to Dicey's strict dichotomy, the Upper Tribunal stressed that constitutional conventions were not law: “They are not enforced by courts."45 No one, for example, could seek to enforce in the courts the convention that an incumbent Prime Minister must resign if, after a general election, another party has won a majority in

\footnotetext{
40 Ibid., at [76].

41 Ibid., at [77 - 88]. See Walter Bagehot, The English Constitution (New York 1889), 143.

42 Evans [2012] UKUT 313 (AAC), at [87].

43 Professor Rodney Brazier gave evidence for the Government Departments (joined as additional parties), but his approach was regarded by the Tribunal as involving "a massive extension of the education convention" (para. 103); see further below.

44 Evans [2012] UKUT $313(\mathrm{AAC})$, at [89-112].

45 Ibid., at [66].
} 
the House of Commons: "there is no law which says that such a Prime Minister must resign". In that rather literal sense of Dicey's dichotomy, the Tribunal was plainly correct. It is not clear, however, that in the current circumstances such literalism was apposite. A Prime Minister's obduracy in the face of election defeat is rather unlikely to be pertinent to a cause of action in judicial proceedings. In the present context, by contrast, law and convention were apparently entwined: the resolution of a question of law depended, at least to some degree, on the correct (or most persuasive) understanding of convention. The Tribunal sought to reconcile its engagement with convention with its view of the proper limits of its jurisdiction:

The parties invite us to decide the extent of the constitutional convention. It is only rarely that a court or tribunal has to decide a question of that kind, and it is a task which we undertake with circumspection. We are not deciding an issue of law. ${ }^{46}$

The parties' invitation could hardly be refused, however, if the true extent of the education convention were a significant aspect of the balancing process required by statute. The Tribunal's conclusions may not provide a definitive account, binding on either ministers or the Prince of Wales as regards their future conduct. But for the purposes of the current proceedings the scope of the convention was arguably no less a matter of law than any other constitutional consideration pertinent to the Tribunal's conclusions. It was a question of law in the sense that it was integral to an interpretation of the "unwritten" constitution, which provided the context in which the balancing exercise had to be undertaken. If, as the Tribunal emphasized, "the major constitutional conventions are core elements in the United Kingdom's parliamentary democracy ${ }^{\prime \prime}{ }^{47}$ they inevitably provided a major part of the normative landscape in which the statutory duties of

\footnotetext{
46 Ibid., at [68].

47 Ibid., at [67].
} 
disclosure fell to be defined and enforced. The major conventions were an essential part of the interpretative context in which the relevant questions of law arose-a context that defined the scope of the plausible answers. ${ }^{48}$

If, of course, identifying the nature and extent of a constitutional convention involved only recording the views of the political actors, or ascertaining the majority view where opinion is divided, the court's conclusions could be fairly categorized instead as a matter of fact. The conventional requirements relevant to legal judgment would be part of the factual background but impose no evaluative obligation on judges. When, however, the requirements of convention are controversial, the politicians divided about their content in particular instances, the court is inevitably drawn into the debate. Even a majority view may be misguided in the sense that, on close scrutiny, it lacks a secure basis in established practice or rests on notions at odds with other important constitutional norms. ${ }^{49}$ The court must form its own view of the matter after studying the precedents and probing the reasons offered in support of competing accounts of the pertinent convention. The Upper Tribunal's acceptance of the "Jennings test" for the existence of a convention-and the broad scope contended for-underlines the point:

As regards the scope of the education convention, we must apply the three elements of that test. First, we must consider whether there is at least one precedent underpinning such a scope. Second, we must consider whether both parties to it considered themselves to be bound to treat Prince Charles's education in the business of government, with its special constitutional status and associated special degree of

\footnotetext{
48 Even Dicey warned that "a lawyer cannot master even the legal side of the English constitution without paying some attention to the nature of those constitutional understandings which necessarily engross the attention of historians or of statesmen" (Lectures Introductory, above, 185).

49 Compare with Geoffrey Marshall, Constitutional Conventions: The Rules and Forms of Political Accountability (Oxford 1984), 10 - 12, distinguishing between "positive morality" and "critical morality".
} 
confidentiality, as extending not merely ... to government informing Prince Charles about what it is doing and responding to queries from him. Third, we must consider whether there is a reason, in the sense used by Jennings ... for the convention to have that scope. ${ }^{50}$

Sir Ivor Jennings had drawn a telling analogy between law and convention:

As in the creation of law, the creation of a convention must be due to the reason of the thing because it accords with the prevailing political philosophy, it helps to make the democratic system operate, it enables the machinery of state to run more smoothly and, if it were not there, friction would result. ${ }^{51}$

In addressing "the reason of the thing" the Tribunal had necessarily to make its own judgments about the merits of the competing conceptions of the education convention. The interpretative task-making the best possible sense of the precedents-was precisely analogous to its common law equivalent. It was only by placing the relevant opinions and precedents within the larger constitutional framework-the complex tapestry of rights, responsibilities and expectations—-that the judges could draw the correct (most plausible) conclusion. The education convention was for all practical purposes law, providing the appropriate legal standard for judging between the respective claims.

The Upper Tribunal's view of the nature and scope of the education convention was central to its decision in favour of disclosure. By rejecting the Departments' contention that the convention was wide enough to cover all correspondence between Government and the heir to the throne, the Tribunal set its face against any presumption of secrecy. It

\footnotetext{
50 Evans [2012] UKUT 313 (AAC), at [75].

51 Sir Ivor Jennings, The Law and the Constitution, 5th ed. (London 1959), 131, cited by the Upper Tribunal at para. 74 .
} 
was noted that Professor Brazier's evidence, supporting a broad conception of the education convention, apparently conflicted with his previous writings, which had suggested the recognition of a new and distinct convention, allowing the Prince of Wales to comment confidentially on ministers' policies and urge adoption of alternative policies. ${ }^{52}$ The logical consequence of accepting Brazier's extended view of the education convention would be that it covered both "advocacy correspondence" and also correspondence on charitable or social matters, even though in cross-examination he resiled from his stance in relation to charitable and social matters. The evidence did not support the view that either Prince Charles or ministers regarded the advocacy correspondence as part of his preparation for kingship; it was acknowledged that his role as King would be quite different. Nor was there good reason for the proposed extension of the convention: "It would be inconsistent with the tripartite convention to afford constitutional status to the communication by Prince Charles, rather than the Queen, of encouragement or warning which ministers might then take account of." 53

Although the Departments sought to rely on the importance of Charles's preparation for kingship, even when such preparation fell outside the proper limits of the education convention, the Tribunal firmly rejected this as a general basis for nondisclosure. Any parallel between advocacy interchanges and the monarch's interaction with Government by way of encouragement and warning was false. While it was conceivable that communications might fall outside the education convention but nonetheless be properly regarded as an aspect of preparation for kingship—such as a discussion between Charles and the Prime Minister about future operation of the tripartite convention-they would not include the correspondence presently in issue:

\footnotetext{
52 Evans [2012] UKUT 313 (AAC), at [92 - 112]. See Rodney Brazier, “The Constitutional Position of the Prince of Wales" [1995] P.L. 401, 404 - 405.

53 Evans [2012] UKUT 313 (AAC), at [106].
} 
The "to and fro" between Prince Charles and government involved in advocacy communications may carry an incidental benefit of increasing Prince Charles's knowledge of how government works, but unless there is some additional element they cannot properly be described as preparation for kingship. ${ }^{54}$

The Tribunal's analysis of the nature and scope of the education convention, therefore, played a central role in its appraisal of the respective public interests. The convention gave shape and precision to a balancing exercise that might otherwise have lacked clarity and rigour.

The position is analogous to the Crossman Diaries case, where Widgery L.C.J. acknowledged the relevance of the convention of collective ministerial responsibility (and Cabinet confidentiality) to the balance of public interests. ${ }^{55}$ The Attorney General's right to prevent publication of the former minister's diaries, recording Cabinet discussions, depended on showing that protection of confidentiality, in accordance with convention, was important enough in all the circumstances to warrant the interference with freedom of speech. He could not succeed unless he could establish both the content and importance of the convention-that the principle of Cabinet confidentiality could in principle justify a limitation of free speech-and further that the issue of an injunction was warranted on the facts, when the material in question was no longer relevant to current events. The rationale and scope of constitutional convention were as critical to the court's decision, therefore, as they were to a properly reasoned decision by the Upper Tribunal in Evans. In both cases, a balanced and compelling judgment as regards the public interest depended, in large measure, on a convincing account of the requirements of constitutional convention.

\footnotetext{
54 Ibid., at [174].

55 Attorney General v Jonathan Cape [1976] Q.B. 752; see further Allan, Sovereignty of Law, 65 - 67.
} 
It is in this context that the question arises as to whether the Attorney General could be thought to have had reasonable grounds for his view that the balance of public interests lay in favour of non-disclosure. How far, if at all, was he permitted to dissent from the Tribunal's view of the constitutional position, which denied any special constitutional status to the Prince's advocacy correspondence? Should the Tribunal's view of the constitutional conventions be treated as authoritative-whether treated as conclusions of law or fact-and so binding on the Attorney in the absence at least of manifest error? Or should the conventions be treated as merely one aspect of a broader question of public policy or public interest, on which the Attorney was entitled to disagree with the Tribunal?

In denying that the Attorney was merely adopting his own view of the public interest, Lord Mance elevated the constitutional conventions to the status of law or fact. In his view, the certificate was based essentially on differences in the Attorney's "account of the relevant circumstances, including the constitutional conventions, by reference to which the relevant issues of public interest fell to be evaluated". ${ }^{6}$ In apparent disregard of the Tribunal's detailed reasoning, the Attorney General had asserted his contrary view:

Discussing matters of policy with Ministers, and urging views upon them, falls within the ambit of "advising" or "warning" about the Government's actions. It thus entails actions which would (if done by the Monarch) fall squarely within the tripartite convention. I therefore respectfully disagree with the Tribunal's conclusion that “advocacy correspondence” forms no part of The Prince of Wales' preparations for kingship..$^{57}$

\footnotetext{
56 Evans [2015] UKSC 21, at [132].

57 Attorney General's certificate, para. 9 (quoted by Lord Mance at [132]).
} 
Lord Mance, however, would permit the Attorney General to substitute his own view about the constitutional principles in play only if he could point to a specific flaw in the Tribunal's reasoning:

The certificate does not engage with, or begin to answer, the problems about this apparently wholesale acceptance of Professor Brazier's thesis about the emergence of a new or highly expanded constitutional convention, which the Upper Tribunal had so forthrightly and on its face cogently rejected. ... It does not address the fact that advocacy correspondence of the kind under discussion has no precedent, is not undertaken as part of and is not necessary as part of any preparation for kingship..$^{58}$

The extent of the education convention did not subsume all the relevant issues; there was apparently scope for the Attorney General to differ from the Tribunal even if he were clearly wrong about that issue. As Lord Wilson and Lord Hughes were keen to emphasize, the Attorney's view was that the advocacy correspondence served to familiarize Prince Charles with the practice of government, and so in that sense formed part of his preparation for kingship, whether or not such correspondence fell within the strict definition of the education convention. If, however, the correspondents had not themselves regarded the exchanges as being in preparatory mode, and if it were conceded that, as King, Charles would conduct himself quite differently, the Attorney's stance was decidedly weak. Stripped from the context provided by the constitutional conventions, the whole notion of "preparation for kingship" was too vague to form a convincing basis for the Attorney's view. It was only in the most attenuated sense that the Prince's advocacy correspondence could be claimed to serve the "very same underlying and

58 Evans [2015] UKSC 21, at [137]. 
important public interests which the education convention reflects". ${ }^{99}$ The Attorney's claim, moreover, that a lack of confidentiality, inhibiting the candid exchange of views, would damage the Prince of Wales's "preparation for kingship" also rested on the dubious assertion that the correspondence served that purpose (as Lord Mance pointed out). ${ }^{60}$

There was a further issue about whether publication of the letters might endanger the Prince's reputation for party-political neutrality. In stressing this possibility the certificate again contradicted the clear findings of the Tribunal. The Tribunal, as Mance observed, had robustly denied that public discourse left no space for public figures to express influential views without appearing politically partisan, or that "secrecy should, in effect, outweigh transparency for fear of 'misperception'"' ${ }^{61}$

In treating all these matters as the "relevant background" to any appraisal of the public interest, Lord Mance substantially narrowed the Attorney's discretion. In substance, if not in so many words, Mance's opinion amounts to an objection to the minister's overriding the Tribunal on questions of law. The "relevant circumstances" in which the respective public interests fell to be evaluated consisted in the correct understanding of constitutional norms. As Lord Wilson observed, the certificate disclosed no disagreement with the Tribunal on any issue of fact "in any ordinary sense of that word". ${ }^{62}$ These were matters of judgment in which issues of fact and assessments of risk were intermixed with questions of legal and constitutional principle. The Tribunal's reluctance to accede to any exaggerated assertions of risk to the Prince's perceived neutrality was based on its commitment to the general principles of openness and freedom of speech. It had pertinently observed that "the essence of our democracy is that criticism

\footnotetext{
59 Attorney General's certificate, para. 9 (quoted by Lord Wilson at [182]).

${ }^{60}$ Evans [2015] UKSC 21, at [138 - 139]; the claim was also "contrary to the clear and reasoned findings of the Upper Tribunal"' (para. 139).

${ }^{61}$ Ibid., at [142].

${ }^{62}$ Ibid., at [182].
} 
within the law is the right of all, no matter how wrongheaded those on high may consider the criticism to be" ${ }^{\prime 63}$

In Lord Mance's view, it was not "open to the Attorney General to issue a certificate ... on the basis of opposite or radically differing conclusions about the factual position and the constitutional conventions without, at the lowest, explaining why the tribunal was wrong to make the findings and proceed on the basis it did". ${ }^{64}$ It was not permissible, we may fairly conclude, because the balancing process took place in the context of a scheme of constitutional principles, which should be correctly understood. The fact that the relevant principles were partly embodied in conventions, reflecting settled political practice, could make no important difference. Judicial exposition of the nature and scope of these conventions, grounded in an exploration of the underlying principles, made a significant contribution to constitutional law. In substance, therefore-if by a more indirect and ambiguous route-Lord Mance followed Lord Neuberger in invoking the basic precept that a member of the executive cannot normally override a judicial decision, made on the basis of a full public hearing into interrelated questions of law, fact, and public interest.

Lord Wilson's approach, by contrast, invokes a more rigid distinction between law and fact, on the one hand, and public policy or public interest, on the other. In his view, the Attorney General disagreed with the Tribunal not on any question of fact or law but, instead, "in its approach to the evaluation of the rival public interests". ${ }^{65}$ Insofar as the constitutional conventions are acknowledged as having any importance, they recede into

\footnotetext{
${ }^{63}$ Evans [2012] UKUT 313 (AAC), at [188] (quoted by Lord Mance at [141]). In general, the Commissioner had not given sufficient weight to the public interest in disclosure: “Those who seek to influence government policy must understand that the public has a legitimate interest in knowing what they have been doing and what government has been doing in response, and thus being in a position to hold government to account. That public interest is ... a very strong one, and in relation to the activities of charities established or supported by Prince Charles it is particularly strong (para. 160).

${ }^{64}$ Evans [2015] UKSC 21, at [145].

65 Ibid., at [182].
} 
the all-embracing category of public interests. He thought there was "a surprising concentration in the evidence before the tribunal and in its judgment on the theoretical ambit of constitutional conventions", especially the education convention:

To determine whether a particular piece of correspondence fell within the ambit of the education convention or some other convention was not to determine the central question, which was whether the public interest in not disclosing it outweighed the public interest in disclosing it. ${ }^{66}$

Since a disagreement about the evaluation of conflicting public interests could not constitute a point of law for the purpose of an appeal to the Court of Appeal, Wilson concluded that the issue of a certificate under section 53 was the Government's only option. The conclusion ultimately depends, however, on the resilience of the distinctions between law, fact, and public interest that Wilson largely takes for granted. However we choose to classify constitutional convention, in particular, for the purposes of descriptive analysis, from an interpretative perspective these distinctions are more tenuous and context-dependent. Their coherence depends on the substantive legal analysis in which they are deployed, as Mance's judgment amply demonstrates. It is only his willingness to submerge the issue of convention within the general category of public interest that enables Wilson to embrace the very doubtful notion of "preparation for kingship".

It is interesting to compare the response of Davis L.J. in the Divisional Court to a submission (on behalf of Evans) that the matters considered by a court or tribunal were to be categorized as either law, fact, or mixed law and fact-all immune from interference by the executive in the absence of some special reason, such as the emergence of fresh evidence. Denying that the Attorney General had purported to disagree with any findings of law or fact, Davis L.J. stressed that what was involved was "a value judgment as to

66 Ibid. 
where the balance of the public interest lies": it depended on "the weight to be accorded to the various competing factors" ${ }^{67}$ There is an assumption here that beyond the strict limits of law and fact, narrowly defined, the Tribunal's findings could be overturned without constitutional affront. That preferred categorization, however, arguably begs the question in favour of the executive. ${ }^{68}$ Davis L.J. noted that "major questions arose in this case from the extent of, and application of, constitutional conventions-which (as the Upper Tribunal itself noted) are not matters of law, as such at all". They were not, as such, issues of law, however, only because the judge chose to draw the boundaries of public law narrowly: the relevant issues of public interest and those concerning "the applicability and extent of conventions" could, having regard to "their constitutional and political overtones", be said to fall "within the domain of government ministers". ${ }^{69}$

The Justices' appraisal of the reasonableness of the Attorney General's conclusions was necessarily rooted in these divergent understandings, resulting in conflicting judgments. Lord Wilson accepted that "once the Upper Tribunal's determination was disseminated, the Attorney General's opinion would be reasonable only if, in his statement of reasons, he demonstrated engagement with its reasoning". ${ }^{70}$ Such engagement need not penetrate, however, far beyond an assertion of his own conclusions: it was apparently enough that the Attorney had summarized the Tribunal's conclusions and stated his disagreement as regards the overall balance of interests. For Lord Hughes, it was enough that the Attorney had "explained in general terms where he differs and

\footnotetext{
67 Evans [2013] EWHC 1960 (Admin), at [108] (judge's emphasis).

68 Compare Lord Dyson M.R. in the Court of Appeal [2014] EWCA Civ. 254, at [38]: “The fact that a section 53(2) certificate involves making an evaluative judgment (rather than a finding of primary fact) is not material to whether the accountable person has reasonable grounds for forming a different opinion from that of the tribunal."

69 Evans [2013] EWHC 1960 (Admin), at [109].

70 Evans [2015] UKSC 21, at [181].
} 
why, so that his reasoning can be understood". ${ }^{71}$ Lord Mance, by contrast, required a much more detailed and cogent response to the Tribunal's reasoning, identifying any flaws that could justify drawing different conclusions. Whereas Wilson and Hughes showed great deference to the Attorney's judgment, Mance demanded close adherence to the Tribunal's reasoning in the absence of persuasive demonstration of error. While law for the dissentients is largely equated with an authoritative source of executive power-the discretion conferred by section 53-law for Mance is assimilated, instead, to reasoned argument, drawing on legal principles and established constitutional practice.

What may appear on the surface to be rather technical arguments about how to draw necessary analytical distinctions or determine the appropriate standard of review turn out, on closer inspection, to be expressions of radically different legal philosophies. Although it is certainly possible to sever questions of public interest or policy from matters of legal principle or constitutional convention, in the manner of the dissenting opinions, the legitimacy of doing so-in the specific context of a ministerial act purporting to override a judicial determination of the same issues-is necessarily part of the legal argument. While, for example, the marginalization of the education convention serves to make questions about "preparation for kingship" more open to non-expert opinion, it also weakens the legal protection afforded to freedom of information and freedom of speech. An insistence on the correct definition of the education convention-denying constitutional status to correspondence falling outside it—serves to undermine dubious assertions of immunity from ordinary duties of disclosure. Deprived of the benefit of the convention, correctly ascertained, the case for non-disclosure of the Prince's advocacy correspondence was very substantially weakened.

71 Ibid., at [162]. 


\section{CONCLUSION}

The significance of constitutional convention for the correct resolution of Evans depended, necessarily, on the correct interpretation of the Freedom of Information Act 2000. If the Attorney General were free to make his own assessment of the competing public interests, regardless of the detailed analysis made by the Upper Tribunal, he could sidestep questions about the scope of the education convention as being of marginal concern. He could fall back on assertions about preparation for kingship, ignoring the Tribunal's considered and cogent objections. If, however, the Attorney were instead required to address the findings of the Tribunal, giving good reasons for doubting their validity, his purported exercise of the veto under section 53 was very dubious. The correct delineation of the education convention was a central pillar of the Tribunal's determination; a conscientious attempt to engage with its findings would entail a convincing critique of its analysis, which the minister did not provide. A persuasive account of constitutional convention was an integral part of the correct resolution of the balance of interests required by statute.

In the Supreme Court two sharply divergent approaches were defended. Lord Neuberger extended the province of law, as finally articulated by the courts, to all the relevant findings of the Tribunal, including the balance of public interests. Lord Hughes and Lord Wilson sought to erect a conceptual wall between matters of law and fact, narrowly defined, on the one hand, and those of constitutional convention and general public interest, on the other. The dissentients' apparent concession, however, that the Attorney should be required to address the Tribunal's findings, rather than simply rejecting its decision, seems fatal to the coherence of their position. Lord Mance, who took that requirement seriously, objecting to the Attorney's cursory dismissal of the Tribunal's meticulous analysis, left little scope in practice for legitimate disagreement-in the absence, at least, of exceptional circumstances of the kind acknowledged by Lord Neuberger. 
The commitment to articulate rationality —an insistence that rejection of the Tribunal's findings should be based on rational grounds, properly explained-demolishes rigid distinctions between law, fact, and public interest. Such distinctions prove too crude to accommodate the constitutional context, in which matters of legal principle demand sensitive application to the circumstances in view. ${ }^{72}$ How should the delineation of convention be categorized? It cannot be simply a matter of fact: there is a normative dimension that demands interpretation of practice, dependent on reasons that the interpreter (in the last analysis) finds compelling. ${ }^{73}$ Nor can convention be properly classed as an aspect of public policy, subject to ministerial discretion as part of an overall political assessment of the needs of the moment. It encapsulates political principle, serving when necessary to guide and constrain such overall assessment of more immediate interests. If convention is not law in the sense that it can be judicially determined in a manner that is authoritative for all purposes, it is nevertheless pertinent to the content of the law when a court must assess competing public interests in resolving interrelated questions of public law and political practice. In that limited sense, at least, it is law-the sense in which it is "recognized" as a legitimate guide to the correct resolution of a legal controversy. ${ }^{74}$

\footnotetext{
${ }^{72}$ For a comparable rejection of any clear-cut doctrinal distinction between law and fact in the context of error of law, acknowledging the distinction's sensitivity to the demands of the particular statutory scheme, see Jones (by Caldwell) v First Tier Tribunal and Criminal Injuries Compensation Authority [2013] UKSC 19, [2013] 2 A.C. 48 : the division between law and fact must take account of policy considerations, including the relative competencies of the tribunal of fact and the appellate court or tribunal (paras. 41 - 47, Lord Carnwath).

73 See further Allan, Sovereignty of Law, ch. 2.

74 Joseph Jaconelli has rejected my earlier critique of the distinction between "recognition" and "enforcement" of conventions, defending instead a "clear conceptual divide between laws and conventions": Jaconelli, “Do Constitutional Conventions Bind?" [2005] C.L.J. 149, at 153, 160 - 61. I have not, however, argued (as Jaconelli appears to suppose) that a breach of convention, standing alone, "could furnish a freestanding cause of action". See further Allan, Sovereignty of Law, 65 - 72.
} 
We must conclude that these conceptual distinctions were deployed in service of competing visions of public law. They were invoked by the dissentients in Evans to diminish the sphere of reasoned deliberation, as it pertained to the requirements of law, in order to preserve a larger field of political discretion for elected politicians. Lord Wilson looked to Parliament to provide the necessary scrutiny of the ministerial veto. However, we can only determine the correctness of his preferred division of powers between legislature and judiciary, in all the circumstances, by reflection on the wider constitutional context. We must ensure that the "unique array of safeguards" provided by the Act are interpreted in a way that does, to the best of our ability, remove the threat we perceive to the rule of law. ${ }^{75}$ When the Attorney General is required by statute to satisfy himself of the legality of the non-disclosure of documents-not merely signal his view of the balance of public interests-it is somewhat anomalous if he is entitled, nonetheless, to substitute his own view for that of a superior court. ${ }^{76}$

The response that the Attorney was bound by the court's view of the law, or even of both law and fact, but not by the court's appraisal of the public interest, is not unproblematic, as several of the Justices appreciated. It presupposes that these distinctions can be sustained in practice without undermining the court's authority; and, as Lord Mance's judgment shows, that was a very doubtful assumption. The question of legality was closely bound up with an appraisal of the respective arguments for and against disclosure. And central to these arguments were the nature and scope of the education convention, which could not-without prejudice to the integrity of the argument—be dismissed as inherently "political", irrelevant to the legal issues arising.

75 See Evans [2015] UKSC 21, at [172]; see n. 23 above.

76 As Laws L.J. observed, in discussing implicit conditions of Parliament's sovereignty, the rule of law entails that "statute law has to be mediated by an authoritative judicial source, independent both of the legislature which made the statute, the executive government which (in the usual case) procured its making, and the public body by which the statute is administered": R. (Cart) v Upper Tribunal [2009] EWHC 3052 (Admin), [2010] 2 W.L.R. 1012, at [36]. 
When matters of public interest are remitted to courts or tribunals, charged to reconcile competing rights or freedoms, the erection of artificial doctrinal barriers to judicial review endangers the rule of law. It disrupts the full elaboration of reasoned argument that is, in the final analysis, the lifeblood of the ideal of due process of law. ${ }^{77}$

That ideal of the rule of law as the rule of reason-an insistence on rigorous analysis of all relevant questions, imposing onerous constraints of coherence and consistency-was implicit in the majority judgments in Evans. Legal judgment is moral judgment in which we seek the correct (or most defensible) answer, having regard to the most plausible and compelling interpretation of the relevant legal materials. There is no short cut available that rests on anyone's personal authority or preference. Admittedly, we do not suppose that there is a correct legal answer to every matter remitted to the discretion of a public authority; we grant such discretion to enable public policy to be developed as executive officials see fit. But submission of a question to the jurisdiction of a court invokes the accompanying constraints of the rule of law: we should normally accept the result as the legitimate outcome of an open, impartial process for resolving a specific dispute. ${ }^{78}$

\footnotetext{
${ }^{77}$ I have suggested that the Canadian Supreme Court mistakenly erected Dicey's descriptive categorization of rules into legal doctrine in Reference re Amendment of the Constitution of Canada (Nos 1, 2, \& 3) (1982) 125 D.L.R. (3d) 1, overlooking the essential role of convention in protecting Canadian federalism from subversion by the manipulation of legal formalities: Allan, Sovereignty of Law, $58-59,69-72$. Transfixed by Dicey's law-convention dichotomy, the Court ignored the implications of its own acknowledgement that the "main purpose of constitutional conventions is to ensure that the legal framework of the Constitution will be operated in accordance with the prevailing constitutional values or principles of the period" (Reference re Amendment, above, 84).

78 Lord Mance observed that "the Upper Tribunal heard evidence, called and cross-examined in public, as well as submissions on both sides. In contrast, the Attorney General ... did not. He consulted in private, took into account the views of Cabinet, former Ministers and the Information Commissioner and formed his own view without inter partes representations": see Evans [2015] UKSC 21, at [130]; compare Lord Neuberger, ibid., at [69].
} 
Admittedly, the ideal of the rule of law is itself a contested one. Any conclusions about the correct judicial approach in Evans connect, as I have suggested, to jurisprudential views about the nature of law and adjudication. In turn, debates within legal philosophy may reflect divergent conceptions of legitimate governance-even if conceptual argument sometimes obscures these underlying differences or purports to be indifferent to them. The link between legality and legitimacy, however conceived, forms an implicit component of any legal conclusion or judgment. As Ronald Dworkin observes, emphasizing the connection between legal argument and legal philosophy: “Jurisprudence is the general part of adjudication, silent prologue to any decision at law."79

A contrasting conception of law, built on a rival account of the rule of law, emphasizes legal certainty, celebrating the simplicity and clarity achieved by curtailing the interpretative process. Closer adherence to the plain or ordinary meaning of statutesdiminishing the role of constitutional principle-attempts to restrict moral debate and deliberation to marginal cases, discouraging disagreement about more central or standard cases. ${ }^{80}$ Doctrinal distinctions, separating the sphere of law, narrowly conceived, from politics or political morality, may serve to limit the judicial role in ways that some readers might prefer. Legal certainty may be enhanced, for example, by adherence to strict interpretative divisions between statute, common law, and convention, even if that means that politicians are freer to manipulate legal forms to achieve ends of questionable propriety. The graver the threat to other constitutional values, however, the less plausible the case for giving priority to legal certainty becomes; and the stronger the challenge to the

\footnotetext{
79 Dworkin, Law's Empire, 90.

80 Compare Dworkin's account of "conventionalism" as a conception of law that reflects an ideal of protected expectations: "Past political decisions justify coercion because, and therefore only when, they give fair warning by making the occasions of coercion depend on plain facts available to all rather than on fresh judgments of political morality, which different judges might make differently" (ibid, 117).
} 
judicial role as defined by the customary separation of powers, the greater the strain placed on doctrinal distinctions that may serve well enough in other contexts.

At any rate, doctrinal distinctions, circumscribing judicial assessments of political principle or the public good, are always in need of justification. They do not reflect features of the world that exist independently of our morally engaged, interpretative efforts to make normative sense of own institutional arrangements. Decisions like Evans show us how superficially trivial differences of judicial opinion, focused on the special features of a single case in all their complex particularity, are often the product, further down, of deeper, more philosophical disagreement about the nature and functions of law. The doctrinal distinctions and methodological assumptions invoked reflect divergent conceptions of legitimate government—what justifies the exercise of judicial authority in ways that politicians or their officials may sometimes find highly inconvenient. Our legal conclusions, then, are only as good as the jurisprudential foundations on which they are necessarily erected. 